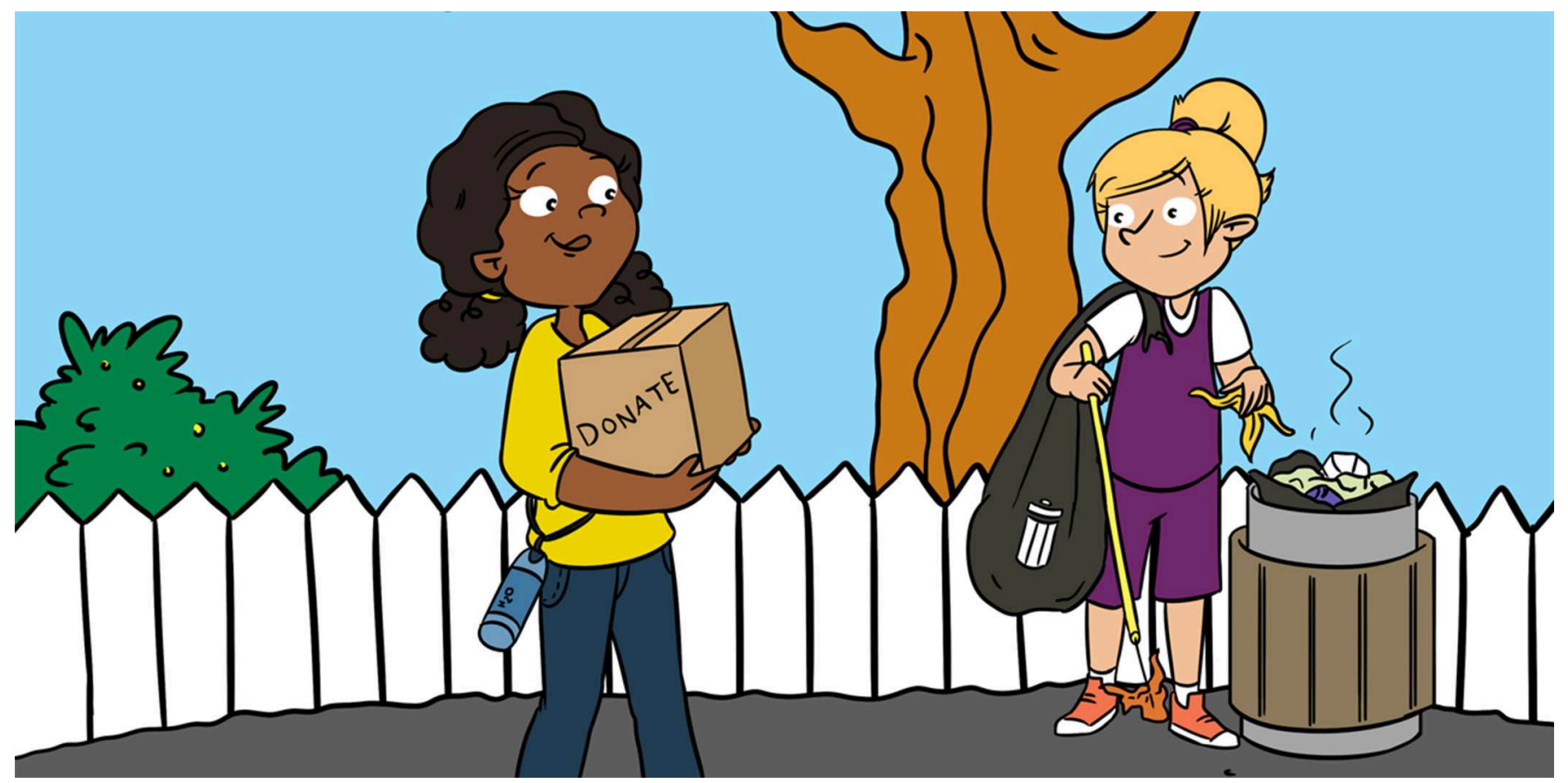

\title{
HOW CAN WE ALL HELP CONSERVE NATURE?
}

\author{
Marcia C. Muñoz ${ }^{1,2}$, Mireia Valle ${ }^{3,4}$, Rachel L. White ${ }^{5}$ and Rodolfo Jaffé ${ }^{6,7^{*}}$ \\ ${ }^{1}$ Instituto de Investigación de Recursos Biológicos Alexander von Humboldt, Bogotá, Colombia \\ ${ }^{2}$ Instituto de Biología, Universidad de Antioquia, Medellín, Colombia \\ ${ }^{3}$ Basque Centre for Climate Change (BC3), Scientific Campus of the University of the Basque Country, Leioa, Spain \\ ${ }^{4}$ National Center for Ecological Analysis \& Synthesis, Santa Barbara, CA, United States \\ ${ }^{5}$ School of Pharmacy and Biomolecular Sciences, University of Brighton, Brighton, United Kingdom \\ ${ }^{6}$ Instituto Tecnológico Vale, Belém, Brazil \\ ${ }^{7}$ Department of Ecology, University of São Paulo, São Paulo, Brazil
}

YOUNG REVIEWERS:

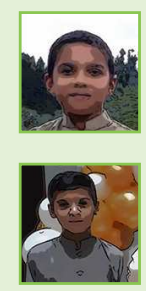

ABDUL

AGE: 12

MUHAMMAD

AGE: 10
When we speak about conserving nature, we are really talking about taking care of our future, because nature provides essential resources for our survival and enjoyment. We asked an international group of scientists working on different environmental issues worldwide to identify important practical actions that we can all do to help conserve nature. We obtained nearly 100 responses and grouped them into three main categories: (1) Actions to reduce our ecological footprint; (2) Actions to conserve nature; and (3) Actions that help us connect with nature. We briefly explain actions that can be performed daily to reduce our impact on nature, and provide some useful links for further reading. 


\section{NATURE}

The term that encompasses living organisms and the forces responsible for the physical world, such as the weather, mountains, oceans, and landscapes.

\section{BIODIVERSITY}

The word biodiversity means the variety of all living organisms on Earth, and includes different levels of organization-from genes, species, and communities through to entire ecosystems.

\section{ECOSYSTEM} SERVICES

The many benefits that people get from natural ecosystems. These services can be broken down into provisioning (e.g., food and wood), supporting (e.g., soil formation and nutrient cycling), regulating (e.g., clean air and water purification), and cultural (e.g., recreation and eco-tourism).

\section{CLIMATE CHANGE}

Change in global or regional climate patterns, most due to increased levels of greenhouse gases produced by the burning of fossil fuels. Greenhouse gases, like carbon dioxide, act like a blanket, trapping heat near the Earth's surface, and raising the temperature.

\section{ECOLOGICAL} FOOTPRINT

This is a measure of how much people take from nature, which is then compared to what natural resources are available to provide for people.

\section{PROTECTING NATURE TO ENSURE OUR FUTURE}

We often forget how much humans depend on nature. Even city-dwellers living in modern skyscrapers need air to breathe, water to drink, and food to eat, all of which are provided by nature. True, you can buy bottled water and ready-to-eat meals in supermarkets, but they were not produced there. Some fruits and vegetables, for example, only grow in tropical countries and cross the globe in refrigerated ship containers, to arrive just ripe to your local supermarket. All drinking water ultimately comes from a natural source, since we still do not have the technology to manufacture large amounts of water in the laboratory [1]. The same applies to the air we breathe, which is purified and oxygenated by plants [2]. So, when we speak about preserving nature, we are really also talking about preserving ourselves.

Whereas nature encompasses the natural environment as a whole, the term biodiversity [3] is used to refer to all living organisms. Biodiversity is ultimately responsible for the services we receive from nature, which are also called Ecosystem Services [4] or Nature's Contribution to People [5]. For example, forests containing many different bee species provide pollination services to nearby crop fields. In places where natural forests have been cut down, beekeepers must bring in artificial beehives to guarantee that enough pollinators visit crop flowers to produce fruit [6]. Other wild organisms, like wasps and birds, act as pest-control agents for agricultural crops, reducing the population of pests that damage those crops, and resulting in higher crop yields.

You are probably thinking that you already knew about this, and that there is not much you can do to preserve air, water, or fruit trees. But even if you live in a big city, far away from oxygen-producing forests, natural water springs, or crop fields, your daily actions can have a strong impact on these natural resources. Spilling a single drop of cooking oil while cleaning the dishes contaminates a million drops of water. Traveling in a vehicle powered by fossil fuels contributes to air pollution and global climate change [7]. Buying certain processed food ingredients, like palm oil, can contribute to massive deforestation in the tropics, as farmers clear land to grow these crops for money. All these impacts together make up what is called our ecological footprint on nature [8], which is a measure to quantify our daily life's impact on nature.

We will now share with you some important practical actions that we can all do to help conserve nature, to preserve our own well-being, and to guarantee that natural resources are available for future generations. 


\section{WHAT ACTIONS CAN WE TAKE TO HELP CONSERVE NATURE?}

We asked an international group of scientists, working on various environmental issues, to provide ideas on what young people can do to help conserve nature. We obtained nearly 100 responses and then organized all of the ideas by grouping them into three main categories: (1) Actions to reduce our ecological footprint (Figure 1); (2) Actions to conserve nature (Figure 2); and (3) Actions to connect with nature (Figure 3). Below we explain each.

Reduce our ecological footprint: Reducing our ecological footprint means placing less demand on nature (read here about the 3Rs-reduce, reuse and recycle; and get some ideas here on how you can help nature). Here are some ways that you can do this:

- Recycle your rubbish and participate in or help organize recycling campaigns.

- Avoid littering and participate in or help organize litter clean-ups (here you can link to a website for volunteering or starting your own beach clean-up).

- Use less plastic by, for example, carrying a reusable water bottle, saying no to disposable straws and cutlery, avoiding plastic toys, and bringing your own shopping bags (for further ideas on a plastic-free life take a look here).

- Swap toys, movies, and books instead of buying new ones.

- Donate, recycle, and repair electronic devices (see how here).

- Use less water when brushing teeth, taking a shower, or washing the dishes.

- Use less electricity by turning off lights and electronic devices when not in use, using energy-saving light bulbs, and hanging clothes to dry.

\section{Figure 1}

Word cloud showing the key actions that can be taken to reduce our ecological footprint. 
- Use public transport, share a journey with friends (e.g., car-sharing), cycle, or walk when possible.

- Use less paper by not printing unnecessary things and reading e-books.

- Turn down the air conditioning when it is hot and use fans if you are still hot-they use much less power.

- Turn down the heat when it is cold and use sweaters, blankets, and socks to keep warm.

- Do not waste food and try to buy food that is grown locally and in season.

- Eat more non-meat proteins (like beans), less dairy, more vegetables, and more organic food when possible.

- Buy products that do not cause damage to the environment and that have certified labels (such as Rainforest Alliance and Animal Welfare).

- Refuse to buy what you do not need, because every item you do not buy reduces the demand for the production of that item. For example, if everyone stopped buying plastic bags, super markets would stop selling them.

Conserve nature: Conserving nature means to protect, preserve and restore biodiversity. Here are some ways that you can do this:

- Try to prevent your pets from killing/harming wildlife (for some specific advice to help your local birds, see this).

- Do not touch or take home wild animals or plants (see some advice here).

- Plant native wildflowers, fruit trees, and pollinator-friendly plants in your garden or yard (for some related gardening tips, check out this).

Figure 2

Word cloud showing the key actions that can be taken to conserve nature. 
- Make compost to improve soil quality and to help insects (check out a guide to composting here).

- Build and place bat houses, bird houses, and "bee hotels" in your garden, school grounds, and local green spaces (here you can learn how make and manage a Bee hotel).

- Do not buy/keep wild pets at home (such as parrots, song birds, wild cats, or reptiles), in order to avoid supporting illegal trafficking of animals (here you can find more info about illegal wildlife trade).

- Be aware of wild animals crossing the road and respect their paths (here is some further information about the importance of wildlife crossings).

Connect with nature: Connecting with nature means setting aside time to interact with the natural environment. Here are some ways that you can do this:

- Play outside and spend more time in nature (read this link to find out why this is so important).

- Organize trips to explore the national parks/nature reserves close to you.

- Join conservation programs or eco-clubs (see how here).

- Participate in nature-focused citizen science initiatives (learn more about citizen science here and see actual projects you can join here and here).

- Use books or apps to identify the plants and animals around you (check out a cool app here).

- Play games to learn more about nature (check out some fun examples here and here).

- Use websites, blogs or social media to help raise awareness on the importance of conserving nature and share all these ideas).

\section{Figure 3}

Word cloud showing the key actions that can be taken to connect with nature. 


\section{CONCLUSION}

Understanding the importance of nature and biodiversity for our own well-being can really help us to help nature. In this article, we have provided some practical ideas that we can all try to reduce our ecological footprint, conserve nature, and connect with nature. We encourage you to put these ideas into practice and share these actions with your family and friends.

\section{REFERENCES}

1. Ernst, C., Gullick, R., and Nixon, K. 2004. Conserving forests to protect water. Opflow 30:1-7. doi: 10.1002/j.1551-8701.2004.tb01752.x

2. Nowak, D. J., Hirabayashi, S., Bodine, A., and Greenfield, E. 2014. Tree and forest effects on air quality and human health in the United States. Environ. Pollut. 193:119-29. doi: 10.1016/j.envpol.2014.05.028

3. Carrington, D. 2018. What is Biodiversity and Why Does it Matter to Us? Guard. Available online at: https://www.theguardian.com/news/2018/mar/12/what-isbiodiversity-and-why-does-it-matter-to-us

4. Millennium Ecosystem Assessment 2005. Ecosystems and Human Well-being: Synthesis. Washington, DC: Island Press. Available online at: http://www. millenniumassessment.org/documents/document.356.aspx.pdf

5. Díaz, S., Pascual, U., Stenseke, M., Martín-López, B., Watson, R. T., Molnár, Z., et al. 2018. Assessing nature's contributions to people. Science 359:270-2. doi: 10.1126/science.aap8826

6. Potts, S. G., Imperatriz-Fonseca, V. L., and Thompson, H. M. (Eds.). 2016. The Assessment Report of the Intergovernmental Science-Policy Platform on Biodiversity and Ecosystem Services on Pollinators, Pollination and Food Production. Bonn: Secretariat of the Intergovernmental Science-Policy Platform on Biodiversity and Ecosystem Services. Available online at: https://www.ipbes. net/assessment-reports/pollinators

7. Center for Climate and Energy Solutions. Climate Basics for Kids. Available online at: https://www.c2es.org/content/climate-basics-for-kids/ (accessed June, 2019).

8. Global Footprint Network. Ecological Footprint. Available online at: https://www. footprintnetwork.org/our-work/ecological-footprint/ (accessed June, 2019).

SUBMITTED: 28 December 2018; ACCEPTED: 28 May 2019;

PUBLISHED ONLINE: 21 June 2019.

EDITED BY: Becky Louize Thomas, School of Biological Sciences, Royal Holloway, University of London, United Kingdom

CITATION: Muñoz MC, Valle M, White RL and Jaffé R (2019) How Can We All Help Conserve Nature? Front. Young Minds 7:84. doi: 10.3389/frym.2019.00084

CONFLICT OF INTEREST STATEMENT: The authors declare that the research was conducted in the absence of any commercial or financial relationships that could be construed as a potential conflict of interest. 

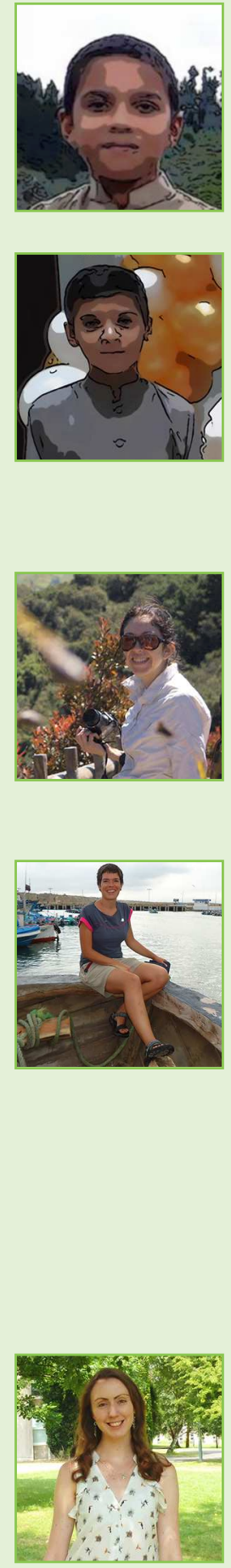

COPYRIGHT @ 2019 Muñoz, Valle, White and Jaffé. This is an open-access article distributed under the terms of the Creative Commons Attribution License (CC BY). The use, distribution or reproduction in other forums is permitted, provided the original author(s) and the copyright owner(s) are credited and that the original publication in this journal is cited, in accordance with accepted academic practice. No use, distribution or reproduction is permitted which does not comply with these terms.

\section{YOUNG REVIEWERS}

\section{ABDUL, AGE: 12}

Abdul is very interested in biodiversity with special attention on extinct or endangered species. He likes learning about life in oceans, on mountains, and wishes to find life in space, if any. He loves drawing nature!

\section{MUHAMMAD, AGE: 10}

Muhammad loves to draw natural environments, hills, rivers, oceans, and prepare 3D structures airplanes, whales, small machines from playdough. He likes the wild animals living in faraway forests where they are not disturbed by humans.

\section{AUTHORS}

\section{MARCIA C. MUÑOZ}

Dr. Marcia Carolina Muñoz is a postdoctoral fellow at the Humboldt Institute in Bogotá, Colombia. Her research focus is centered on beneficial interactions between plants and birds, in particular, seed dispersal and pollination in tropical systems, and the consequences of these interactions on biodiversity. She likes hiking and taking pictures of birds, flowers, and natural landscapes.

\section{MIREIA VALLE}

Dr. Mireia Valle is a postdoctoral researcher from the Basque Centre for Climate Change (BC3) who has been awarded a postdoctoral fellowship by the Basque Government, which covers two years in a foreign research centre and a third year in a research institution in the Basque Country. She is currently performing her research at the National Center for Ecological Analysis and Synthesis at University of California Santa Barbara (EEUU). She wants to understand how and where marine fish will shift due to climate change and the implications of such shifts on the benefits we derive from these fish. She became mum in October 2018 and looks forward to helping to continue to protect nature and ensure a sustainable future for new generations.

\section{RACHEL L. WHITE}

Dr. Rachel L. White is a Senior Lecturer in Ecology and Conservation at the University of Brighton. Her research includes the ecology and conservation of birds, understanding extinction risk, environmental education, and human-nature interactions. She is passionate about sharing her sense of wonder and excitement 
about the natural world with anyone, but particularly with children (who are the next-generation of conservationists).

\section{RODOLFO JAFFÉ}

Dr. Rodolfo Jaffé is a researcher/faculty at Instituto Tecnológico Vale, located at the mouth of the Amazon River in Brazil. He studies how human-led alterations of natural environments affect biodiversity, focusing on insects and plants. He enjoys spending weekends on the beach with family and friends, and hopes his 2-years old daughter enjoys reading this paper when she grows up. *r.jaffe@ib.usp.br 